
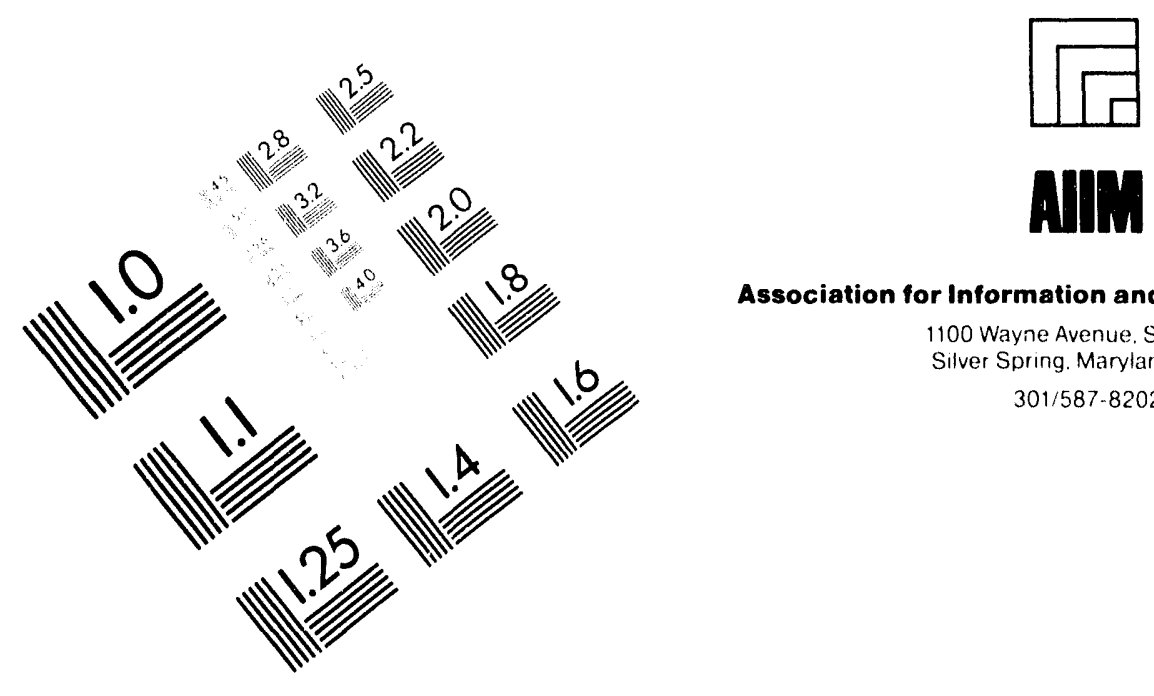

Association for Information and Image Management

1100 Wayne Avenue. Suite 1100

Silver Spring. Maryland 20910

301/587-8202

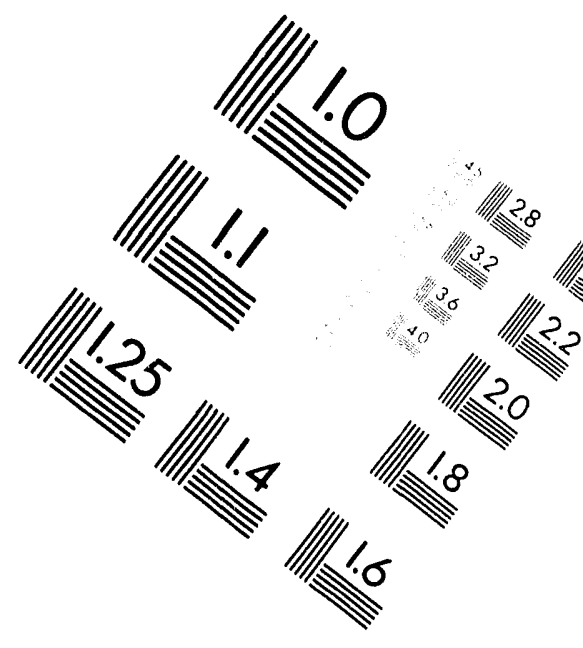

\title{
Centimeter
}

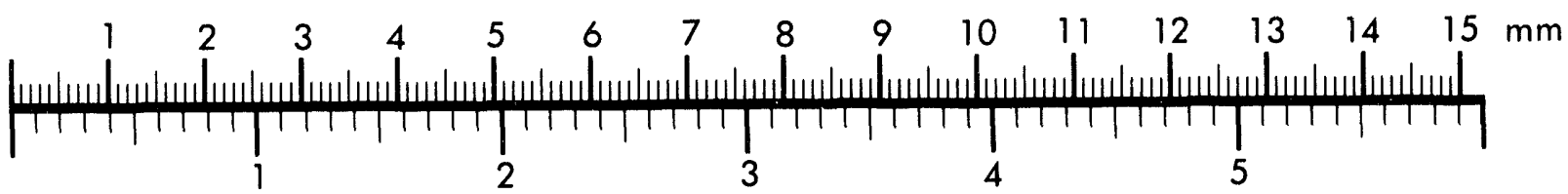
Inches
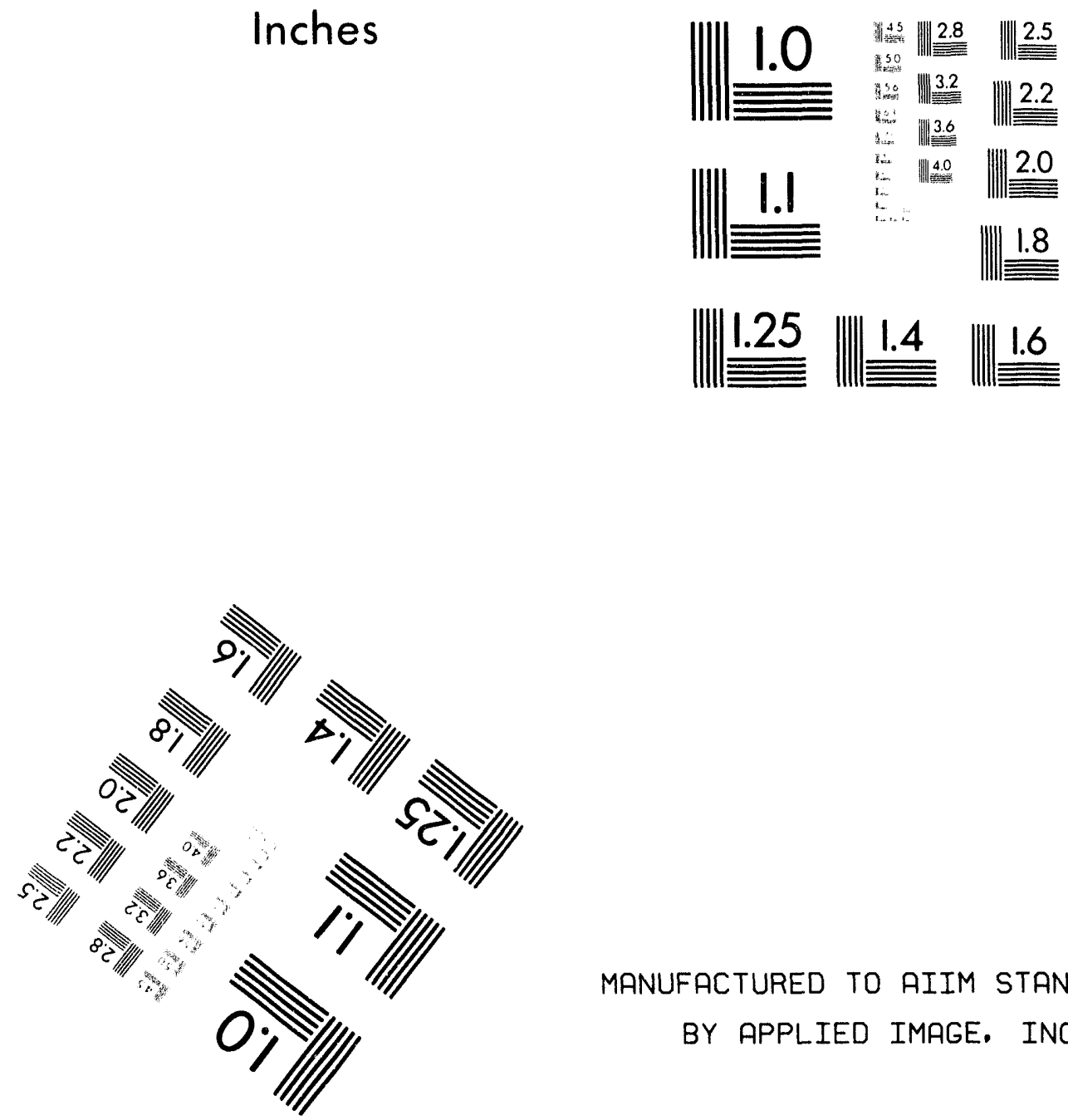

MANUFACTURED TO AIIM STANDARDS

BY APPLIED IMAGE, INC.

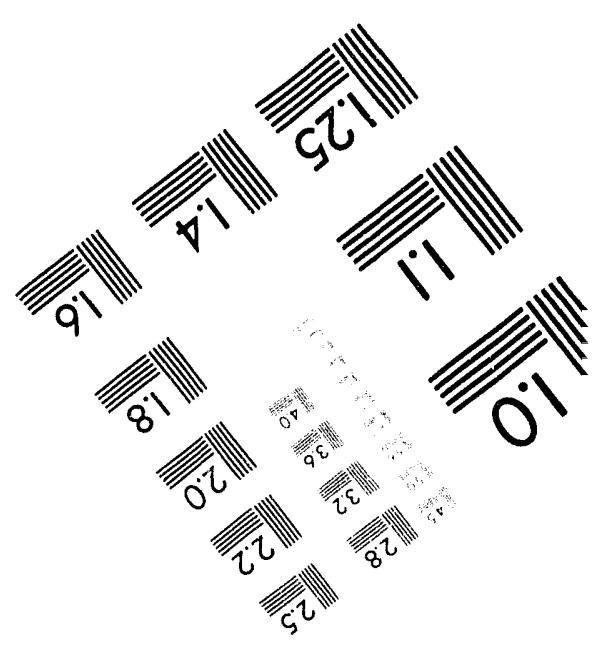





\title{
DISCLAIMER
}

This report was prepared as an account of work sponsored by an agency of the United States Government. Neither the United States Government nor any agency thereof, nor any of their employees, makes any warranty, express or implied, or assumes any legal liability or responsibility for the accuracy, completeness, or usefulness of any information, apparatus, product, or process disclosed, or represents that its use would not infringe privately owned rights. Reference herein to any specific commercial product, process, or service by trade name, trademark, manufacturer, or otherwise does not necessarily constitute or imply its endorsement, recommendation, or favoring by the United States Government or any agency thereof. The views and opinions of authors expressed herein do not necessarily state or reflect those of the United States Government or any agency thereof.

\section{Cellular Oncogene Expression Following Exposure of Mice to $\gamma$-Rays}

\section{JUN $121999^{1}$}

Aaron Anderson ${ }^{1}$

Gayle E. Woloschak

\author{
Argonne National Laboratory \\ Biological and Medical Research Division \\ 9700 South Cass Avenue \\ Argonne, Illinois 60439-4833
}

'Work done while a student in the laboratory of Gayle E. Woloschak. Anderson's current address: Molecular Biology Program, University of Utah, 212 Life Sciences Bldg., Salt Lake City, UT 84112

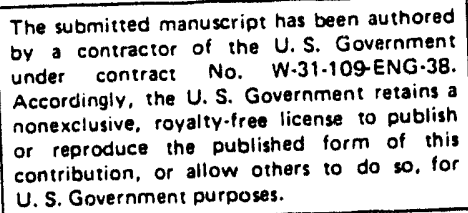

Number of copies submitted: 4

Number of manuscript pages, figures, and tables: 18 
Running head: Oncogene Expression Following $\gamma$ Rays

Person to whom correspondence should be addressed:

Dr. Gayle E. Woloschak

Biological and Medical Research Division

Argonne National Laboratory

9700 South Cass Avenue

Argonne, IL 60439-4833 


\begin{abstract}
Many studies have shown the importance of altered cellular oncogene expression in contributing to the development of neoplasia. In these experiments we examined the effects of total body exposure of $B C F 1$ mice to $\gamma$-rays $(300 \mathrm{CGy}$ ) in modulating expression of cellular oncogeries in both gut and liver tissues. We selected specific cellular oncogenes (c-fos, c-myc, c-src, and c-Hras), based on their normal expression in liver and gut tissues from untreated mice. As early as $5 \mathrm{~min}$. following whole body exposure of BCF1 mice to $\gamma$-rays we detected induction of mRNA specific for c-src and c-H- $\underline{\text { ras }}$ in both liver and gut tissues. c-fos RNA was slightly decreased in accumulation in gut but was unaffected in liver tissue from irradiated mice relative to untreated controls. c-myc mRNA accumulation was unaffected in all tissues examined. These experiments document that modulation of cellular oncogene expression can occur as an early event in tissues following irradiation and suggest that this modulation may play a role in radiation-induced carcinogenesis.
\end{abstract}


Previous work from our group has examined early responses of cells to and associated effects of low doses of ionizing radiation (1-3). This work has documented the induction of several genes, including $\mathrm{c}$-fos, protein kinase $\mathrm{C}$, $\alpha$-tubulin, and interleukin 1 in Syrian hamster embryo (SHE) cells following exposure to $\gamma$-rays $(1,2)$. Experiments by other groups have shown modulation of $c$-fos mRNA following exposure of cells in culture to $x$-rays or other DNAdamaging agents (4-7). We have also demonstrated differential effects from radiation of different qualities on gene modulation in SHE cells, and we are examining events which may ultimately lead to transformation and neoplasia.

Increased expression of cellular oncogenes may play a significant role in the development and progression of transformed cells in vitro and in vivo $(8,9)$. Previous work from our laboratory has shown that c-fos mRNA accumulation in gut is lower following whole body exposure to JANUS neutrons (10), and similar studies by Koropatnick et al. (11) have documented the increased accumulation of metallothionein mRNA following whole body exposure of mice to $x$-rays. The experiments reported here were designed to determine whether the expression of four different cellular oncogenes is altered in mice following exposure to whole-body $\gamma$-rays. We examined the accumulation of cfos, c-myc, c-src, and c-H-ras mRNA at 5 and 60 min following whole-body exposure of BCF1 mice to $300 \mathrm{cGy}$ of ${ }^{60} \mathrm{Co} \gamma$-rays. Our experiments demonstrated increased accumulation of $\mathrm{c}$-src and $\mathrm{c}-\mathrm{H}$-ras $\mathrm{mRNA}$ in liver and gut from irradiated mice relative to controls. The c-fos mRNA levels slightly decreased in gut, while c-myc RNA was unaffected by the exposure. c-myc and c-fos mRNAs in livers of irradiated mice were unaffected. This work documents early alterations in oncogene expression following whole-body exposure to radiation, which suggests a role for these events in radiation-induced cellular transformation and the potential use of the induced transcripts as markers of radiation exposure. 
Mice. All mice were bred at the animal care facilities at Argonne National Laboratory. BCF1 (BALB/C X C57BL/6)F1 mice were 3-6 months of age for all experiments reported here. All data points involved pooled tissues from 3-6 mice. Preliminary experiments revealed no differences in males or females with regard to changes in transcription following radiation exposure (10; Anderson and Woloschak, unpublished observations). For that reason, males and females were mixed in these experiments.

Irradiations. Mice were exposed to $300 \mathrm{cGy}$ (gut dose) of ${ }^{60} \mathrm{Co} \gamma$ rays at a dose rate of $25 \mathrm{cGy} / \mathrm{min}$ for $12 \mathrm{~min}$. This low dose was selected based on minimal death to hematopoietic cells, minimal vascular changes, and no detectable shifts in lymphocyte subpopulation involved following exposure $(10,12)$; this minimized the influence of contaminating vascular cells on the results. We performed all irradiations using the ${ }^{60} \mathrm{Co}$ source at the Biological and Medical Research Division of Argonne National Laboratory. At both $5 \mathrm{~min}$ and $60 \mathrm{~min}$ following completion of irradiation, we asphyxiated the mice and excised tissues. All tissues were frozen on dry ice immediately following removal from the animals. Control (untreated-0) mice were taken to the radiation chamber but were not exposed to radiation.

mRNA Preparation. Tissues were thawed in homogenization buffer, (0.075 $\mathrm{M}$ sodium chloride, $0.025 \mathrm{M}$ disodium EDTA, $0.02 \mathrm{M}$ Tris, $\mathrm{pH} 8.0$, and $0.5 \%$ sodium dodecyl sulfate) and homogenized in a Waring blender with an equal volume of fresh phenol. Following phenol extraction, samples were precipitated from ethanol overnight at $-20^{\circ} \mathrm{C}$. The pellet was dissolved in water and RNA was precipitated from $3 \mathrm{M}$ sodium acetate $(\mathrm{pH} 6.0)$ for $2 \mathrm{~h}$ at $4^{\circ} \mathrm{C}$. Poly A+ RNA was separated from total RNA using oligodeoxythymidylate affinity column chromatography. mRNA was quantitated by monitoring absorbance at $260 \mathrm{~nm}(1,2)$. 
mRNA dot blots and hybridizations. Nitrocellulose filters were wetted in water and soaked in $2 \mathrm{OX} \mathrm{SSC}$ for $15 \mathrm{~min}$ prior to dotting. Each RNA sample $(2 \mu \mathrm{g}, 1 \mu \mathrm{g}$, and $0.5 \mu \mathrm{g})$ was dissolved in water. All blots were baked under vacuum at $80^{\circ} \mathrm{C}$ for $1 \mathrm{~h} \mathrm{(10)}$.

Prior to hybridization, filters were soaked for $15 \mathrm{~min}$ in $3 X \mathrm{XSC}$ and for $2-4 \mathrm{~h}$ with shaking at $43^{\circ} \mathrm{C}$ in hybridization mix [ $50 \%$ formamide, $250 \mu \mathrm{g} / \mathrm{ml}$ sonicated denatured herring sperm DNA, $1 X$ Denhardt's $(0.2 \%$ bovine serum albumin, $0.2 \%$ ficoll, $0.2 \%$ polyvinylpyrrolidone), $50 \mu \mathrm{g} / \mathrm{ml}$ poly $\mathrm{A}, 0.1 \%$ sodium dodecyl sulfate, $11.25 \mathrm{mM}$ sodium citrate, and $0.11 \mathrm{M}$ sodium chloride]. ${ }^{32} \mathrm{P}$-labeled probes were denatured at $90^{\circ} \mathrm{C}$ for $5 \mathrm{~min}$ and cooled on ice before use. Hybridizations were carried out at $43^{\circ} \mathrm{C}$ in the hybridization buffer. Hybridized blots were exposed to $x$-ray film at $-70^{\circ} \mathrm{C}$. Relative quantitation was determined using a Hirshman microdensitometer.

All blots were dehybridized by incubation overnight in $\mathrm{H}_{2} \mathrm{O}$ at $43^{\circ} \mathrm{C}$. They were checked for total removal of the probe by overnight exposure to $x$-ray film. Those blots showing total removal of the initial probe were then rehybridized to a different cDNA clone.

All results reported here were derived from three independent experiments using three independent experimental groups of mice. Student's t-test was used for statistical analysis. The microdensitometric results presented in Tables I and II were derived from those exposures of blots that were within the linear range of the $x$-ray film. Only blots showing equal amounts of RNA capable of hybridizing to the rRNA probe were used in these experiments. It should be noted that while RNA in these experiments is polyA+, there is sufficient contaminating rRNA to detect hybridization following overnight exposure to labeled pHRR rRNA probe. This control allows for checks on both RNA loading onto nitrocellulose filters and also on purity of polyA+ RNA preparations used in all experiments. 
cDNA clones. Clones containing c-fos, c-myc and c-H-ras were obtained from American Type Culture Collection (Bethesda, MD). The c-src-containing plasmid was graciously provided by Dr. A. Balmain (Beatson Institute, Glasgow). The pHRR rRNA probe was obtained from Dr. Eric Weiben (Mayo Clinic, Rochester, MN).

RNA was serially diluted and immobolized on nitrocellulose filters; oncogene-specific mRNAs were quantitated by dot blot hybridization of the RNA to ${ }^{32} \mathrm{P}$-labeled CDNA probes specific for each of four oncogenes. Figure 1 shows dot blots of c-fos, c-myc, c-src and c-H-ras mRNA from liver tissue. The results within the linear range of the film were quantitated by microdensitomentry (Table I). The c-fos and c-myc mRNA levels were unaffected by $\gamma$-ray exposure, while c-src and c-H-ras transcripts were induced in livers of mice exposed to the radiation. This induction occurred as early as $5 \mathrm{~min}$ following completion of the radiation exposure.

Figure 2 shows dot blots of these same oncogene-specific transcripts from gut tissues, with the microdensitometric results presented in Table II. These results demonstrate induction in gut (like liver above) of both c-src and $\mathrm{c}-\mathrm{H}$-ras mRNA within the first 5 min following completion of the exposure of mice to radiation. Expression of $c$-fos mRNA was somewhat reduced relative to controls, while c-myc mRNA was unaffected by the irradiation. All the oncogene-specific transcripts from both the gut and liver tissues were affected similarly by $\gamma$-rays.

This study has demonstrated the alteration of cellular oncogene expression in liver and gut tissues within the first $5 \mathrm{~min}$ following exposure of mice to ionizing radiation. Both c-src and $c-H$-ras were induced following exposure to $\gamma$ rays, while c-myc and $c$-fos were unaffected (except c-fos in gut which was slightly reduced). This suggests that the whole-body response to ionizing radiation is very rapid and that the transcriptional response involves selective modulation of specific oncogenes. It should be noted that the changes in expression observed 
here are relatively small (2- to 3-fold). This is in keeping with experiments from other groups demonstrating only moderate gene modulation following exposure to DNA-damaging agents $(3,4,10,11)$. Since increased expression of some oncogenes (including c-myc and c-H-ras) has been shown to play a role in cellular transformation $(8,9)$, our results also suggest that one mechanism of $\gamma$ ray mediated oncogenesis may involve the modulation of oncogene expression in selected tissues. While our results demonstrate a transient increase in cellular oncogene expression, these early changes may actually predispose the cells to transformation. Pelling et al. have demonstrated that elevated expression of $\mathrm{c}-\mathrm{H}$-ras is an early event in two-stage carcinogenesis in mouse epidermal tissue (13). It is also interesting that $\mathrm{c}-\underline{\mathrm{myc}}$ and c-H-ras have been two oncogenes identified as working in cooperation to transform 3 T3 cells in vitro (14).

The c-myc and c-H-ras are not the first cancer-associated genes found to be induced in livers of irradiated mice. Anscher et al. (15) have shown increased levels of transforming growth factor- $\beta$ ( $\beta$-TGF) up to 9 months following irradiation of rats. They did not identify how early this induction first takes place though repression of $c$-myc expression as a result of $\beta-T G F$ treatment in vitro has been clearly demonstrated (16-17). We do not yet know the temporal relationship of these inductive events in our system. While it is clear that these genes may play a tumorigenic role in irradiated mice, it is also possible that induction of these cellular oncogenes following $\gamma$-ray exposure is associated with some cellular protective effect. It is interesting to note that these inductive events are evident within $5 \mathrm{~min}$ after completion of exposure, a timeframe during which repair is reported to take place (18). Fitzgerald et al. have determined that expression of c-H-ras when expressed at high levels in 3T3 cells is associated with increased radioresistance of cells (19). In fact, high-level expression of c-H-ras or c-src may prove to be a marker of cellular radioresistance, and experiments are underway to examine that hypothesis. Alternatively, increased expression of these genes may depend on the cell growth capabilities 
of the examined tissues. Both gut and liver tissues (which showed similar patterns of oncogene modulation) contain cells capable of repopulation or regeneration in the event of injury. One of the earliest everits that cccurs in the gastrointenstinal tract following $x$-ray exposure is a decrease in enteroendocrine cell number, evident as early as one day following exposure to doses as low as $6 \mathrm{~Gy}(20)$. This is followed by villous damage, endothelial damage caused by plasma leakage, and changes in the vasculature of the intestine (21). It is possible that the induction of c-src or c-H-ras following radiation exposure is a part of this normal response to tissue injury. In fact, other reports have documented induction of $\mathrm{c}-\mathrm{H}$-ras and $\mathrm{c}-\underline{\mathrm{myc}} \mathrm{mRNA}$ in mice given partial hepatectomies to cause liver regeneration (22-23).

The induction of c-src and c-H-ras in gut and livers of mice exposed to $\gamma$-rays does not establish that this will occur in all tissues. Preliminary evidence from our group suggests that brain tissues from these mice are transcriptionally unaffected by these doses of radiation, which is not surprising in light of the radioresistance of neural tissue (Anderson, Panozzo, and Woloschak, unpublished observations). Koropatnick et al. (11) have documented organ-specific effects of $x$-rays on the induction of metallothionein: the liver showed induction of the transcript, while expression in kidney and spleen was unaffected.

Much work in our laboratory has focused on the differential effects or radiation quality on gene expression $(1-3,10)$. Our past work and that of others has shown in vitro induction of c-fos following exposure to low-LET radiation such as $x$-rays and $\gamma$ rays $(3,4)$. This report demonstrates little change in expression of c-fos following whole-body exposure to $\gamma$ rays, although in gut there was a slight but consistent decrease in c-fos mRNA accumulation. In previous experiments examining effects of whole-body exposure of mice to JANUS fissionspectrum neutrons (using equally carcinogenic doses relative to the $\gamma$ rays used here), we demonstrated repression of $c$-fos mRNA expression in gut tissues from exposed mice (10). The 
slight repression of $c$-fos observed here suggests that at higher doses of $\gamma$ rays, the effects may be similar to those observed previously for neutrons. This also suggests that one cannot always extrapolate from the in vitro to the in vivo situation. If so, c-fos would be a member of a class of genes including those for ornithine decarboxylase, interleukin-1, actins, and tubulin (1-3) that responds similarly to both $\gamma$ rays and fission-spectrum neutrons. We do not know the response pattern following neutron exposure of whole mice for the othci oncogenes examined in this study.

\section{Acknowledgments}

The authors wish to thank Chin-Mei Chang-Liu and Gordon Holmblad for assistance in the irradiations, June Lear and Kay Bexson for excellent secretarial assistance, Dave Bertoncini for technical assistance, Dr. Ken Groh for assistance with computers, and Drs. Carol Giometti, Mark Churchill and Frank Collart for critical reviews of the manuscript. This work was supported by the U. S. Department of Energy, Office of Health and Environmental Research, under Contract \# W-31-109-ENG-38. 


\section{References}

1. G. E. WOLOSCHAK, C. -M. LIU, P. SHEARIN-JONES, and C. A. JONES, Modulation of gene expression in Syrian hamster embryo cells following ionizing radiation. Cancer Res. 50, 339-344 (1990).

2. G. E. WOLOSCHAK, C. -M. LIU, and P. SHEARIN-JONES, Regulation of protein kinase C by ionizing radiation. Cancer Res. 50, 3963-3967 (1990).

3. G. E. WOLOSCHAK and C. -M. CHANG-LIU, Differential modulation of specific gene expression following high- and low-LET radiations. Radiat. Res. 124, 183-187 (1990).

4. M. C. HOLLANDER and A. J. FORNACE, JR., Induction of fos RNA by DNA-damaging agents. Cancer Res. 49, 1687-1692 (1989).

5. P. HERRLICH, P. ANGEL, H. J. RAHMSDORF, U. MALLICK, A. POTING, L. HIEBER, C. LUCKE-HUHLE, and M. SCHORPP, The mammalian genetic stress response. Genetic Stress Response 25, 485-504 (1987).

6. P. ANGEL, M. IMAGAWA, R. CHIU, B. STEIN, R. J. IMBRA, J. H. RAHMSDORF, C. JONAT, P. HERRLICH, arid M. KARIN, Phorbol ester-inducible genes contain a common cis element recognized by a TPA-modulated trans-acting factor. Cell 49, 729-739 (1987).

7. B. STIEN, H. J. RAHMSDORF, A. STEFFEN, M. LITFIN, and P. HERRLICH, UVinduced DNA damage is an intermediate step in UV-induced expression of human immunodeficiency virus type 1, collagenase, c-fos, and metallothionein. Molec. Cell Biol. 9, 5169-5181 (1989).

8. G. E. WOLOSCHAK, Association of oncogene activity and hemotologic malignancy. In Current Hematology and Oncology (Virgil Fairbanks, Ed.), Vol. 5, pp. 281-329 1987.

9. J. M. BISHOP, Viral oncogenes. Cell 42, 23-38 (1985). 
10. G. P. MUNSON, AND G. E. WOLOSCHAK, Modulation of c-fos gene expression following JANUS neutron exposure in repair-deficient and repair-deficient mice. Cancer Res. 50, 5045-5048 (1990).

11. J. KOROPATNICK, M. LEIBBRANDT, AND M. G. CHERIAN, Organ-specific metallothionein induction in mice by x-irradiation. Radiat. Res. 119, 356-365 (1989).

12. M. PADILLA, C. LIBERTIN, C. KRCO, AND G. E. WOLOSCHAK, Radiation sensitivity of T-lymphocytes from immunodeficient "wasted" mice. Cellular Immunology 130, 186194 (1990).

13. J. C. PELLING, S. M. ERNST, J. M. STRAWHECKER, J. A. JOHNSON, R. S. NAIRN, AND T. J. SLAGA, Elevated expression of Ha-ras is an early event in two-stage skin carcinogenesis in SENCAR mice. Carcinogenesis 7, 1599-1602 (1986).

14. H. LAND, L. F. PARADA, AND R. A. WEINBERG, Tumorigenic conversion of primary embryo fibroblasts requires at least two cooperating oncogenes. Nature 312, 711-716 (1983).

15. M. S. ANSCHER, J. R. CROCKER, AND R. L. JIRTLE, Transforming growth factor- $\beta 1$ expression in irradiated liver. Radiat. Res. 122, 77-85 (1990).

16. M. B. SPORN, A. B. ROBERTS, L. M. WAKEFIELD, AND R. K. ASSOIAN, Transforming growth factor- $\beta$ : biological function and chemical structure. Science 233, 532-534 (1986).

17. K. TAKEHARA, E. C. LEROY, AND G. R. GROTENDORST, TGF- $\beta$ inhibition of endothelial cell proliferation: alteration of EGF finding and EGF-induced growthregulatory (competence) gene expression. Cell 49, 415-422 (1987).

18. M. M. ELKIND. Repair processes in radiation biology. Radiat. Res. 100, 425-449 (1984).

19. T. J. FITZGERALD, S. HENAULT, M. SAKAKEENY, M. A. SANTUCCI, J. H. PIERCE, P. ANKLESARIA, K. KASE, I. DAS, AND J. S. GREENBERGER, Expression of transfected 
recombinant oncogenes increases radiation resistance of clonal hematopoietic and fioroblast cell lines selectively at clinical low dose rate. Radiat. Res. 122, 44-52 (1990).

20. M. G. WYATT, S. P. HUME, K. E. CARR, AND J. C. MARIGOLD, A preliminary study of the role of gastrointestinal endocrine cells in the maintenance of villous structure following x-irridation. Scanning Microscopy 1, 291-300 (1987).

21. B. ABBAS, F. C. BOYLE, D. J. WILSON, A. C. NELSON, AND K. E. CARR, Radiation induced changes in the blood capillaries of rat duodenal villi: a corrosion cast, light and transmission electron microscopical study. J. Submicroscopic Cytology and Pathology 22, $63-70(1990)$.

22. N. FAUSTO, Messenger RNA in regenerating liver: implications for the understanding of regulated growth. Molec. Cell. Biochem. 59, 131-147 (1984).

23. W. KRUIJER, H. SKELLY, F. BOTTERI, H. VAN DER PUTTEN, J. R. BARBER, I. M. VERMA, AND H. L. LEFFERT, Proto-oncogene expression in regenerating liver is simulated in cultures of primary adult rat hepatocytes. J. Biol. Chem. 261, 1729-1733 (1986). 
Table I. Expression of oncogenes in liver following -rays $^{1}$

\begin{tabular}{lccc}
\hline & & \multicolumn{2}{c}{$\begin{array}{c}\text { Time following } \\
\text { Irradiation }\end{array}$} \\
\cline { 3 - 4 } Transcript & Untreated & 5 & 60 \\
\hline c-fos & $1.0^{3}$ & 0.9 & 1.0 \\
c-myc & 1.0 & 1.2 & 1.0 \\
c-src & 1.0 & $2.1^{*}$ & $1.4^{*}$ \\
c-H-ras & 1.0 & $2.1^{*}$ & $2.7^{*}$ \\
\hline
\end{tabular}

${ }^{1}$ The results are averages based on microdensitometric readings taken from independent experiments similar to those shown in Figure 1.

${ }^{2}$ Time of animal sacrifice and tissue harvest after completion of irradiation.

${ }^{3}$ Relative mRNA levels in untreated mice were set at 1.0. Other values are expressed relative to that. Standard deviations for all experiments were less than or equal to 0.1 .

*significantly different from control at $p<0.001$ based on Student's t-test. 
Table II. Expression of oncogenes in gut following $\gamma$-rays ${ }^{1}$

Time following Irradiation $^{2}$ (2 $\mathrm{min}$ )

\begin{tabular}{lcll} 
Transcript & Untreated & \multicolumn{1}{c}{5} & 60 \\
\hline c-fos & $1.0^{3}$ & $0.8^{* *}$ & $0.8^{* *}$ \\
c-myc & 1.0 & 1.1 & 1.0 \\
c-src & 1.0 & $1.6^{* 4}$ & $1.5^{*}$ \\
c-H-ras & 1.0 & $1.4^{*}$ & $1.1^{*}$ \\
\hline
\end{tabular}

${ }^{1}$ The results are averages based on microdensitometric readings taken from independent experiments similar to those shown in Figure 1.

${ }^{2}$ Time of animal sacrifice and tissue harvest after completion of irradiation.

${ }^{3}$ Relative mRNA levels in untreated mice were set at 1.0. Other values are expressed relative to that. Standard deviations for all experiments were less than or equal to 0.1 .

*significantly different from control at $p<0.001$ based on Student's t-test.

**denotes dignificantly different from control at $P<.05$ based on Student's t-test. 
FIGURE LEGENDS

Figure 1. RNA dot blot examining accumulation of mRNA specific for (A) c-fos, (B) $\mathrm{c}-\mathrm{myc}$ (C) c-src and (D) c- $\mathrm{H}$-ras from livers of $\mathrm{B} 6 \mathrm{C} 3$ mice (0), as well as mice five $\min \left(5^{\prime}\right)$ and $60 \mathrm{~min}\left(60^{\prime}\right)$ following exposure to $300 \mathrm{cGy}$ rrays. Numbers along the side list $\mu \mathrm{g}$ of RNA loaded onto the blot.

Figure 2. RNA dot blot examining accumulation of mRNA specific (A) c-fos, (B) $c-\underline{m y c}$ (C) c-src and (D) c-H-ras from gut tissues of untreated mice (0), as well as mice five $\mathrm{min}\left(5^{\prime}\right)$ and $60 \mathrm{~min}\left(60^{\prime}\right)$ following exposure to 300 cGy $\gamma$-rays. Numbers along the side list $\mu g$ of RNA loaded onto the blot. 

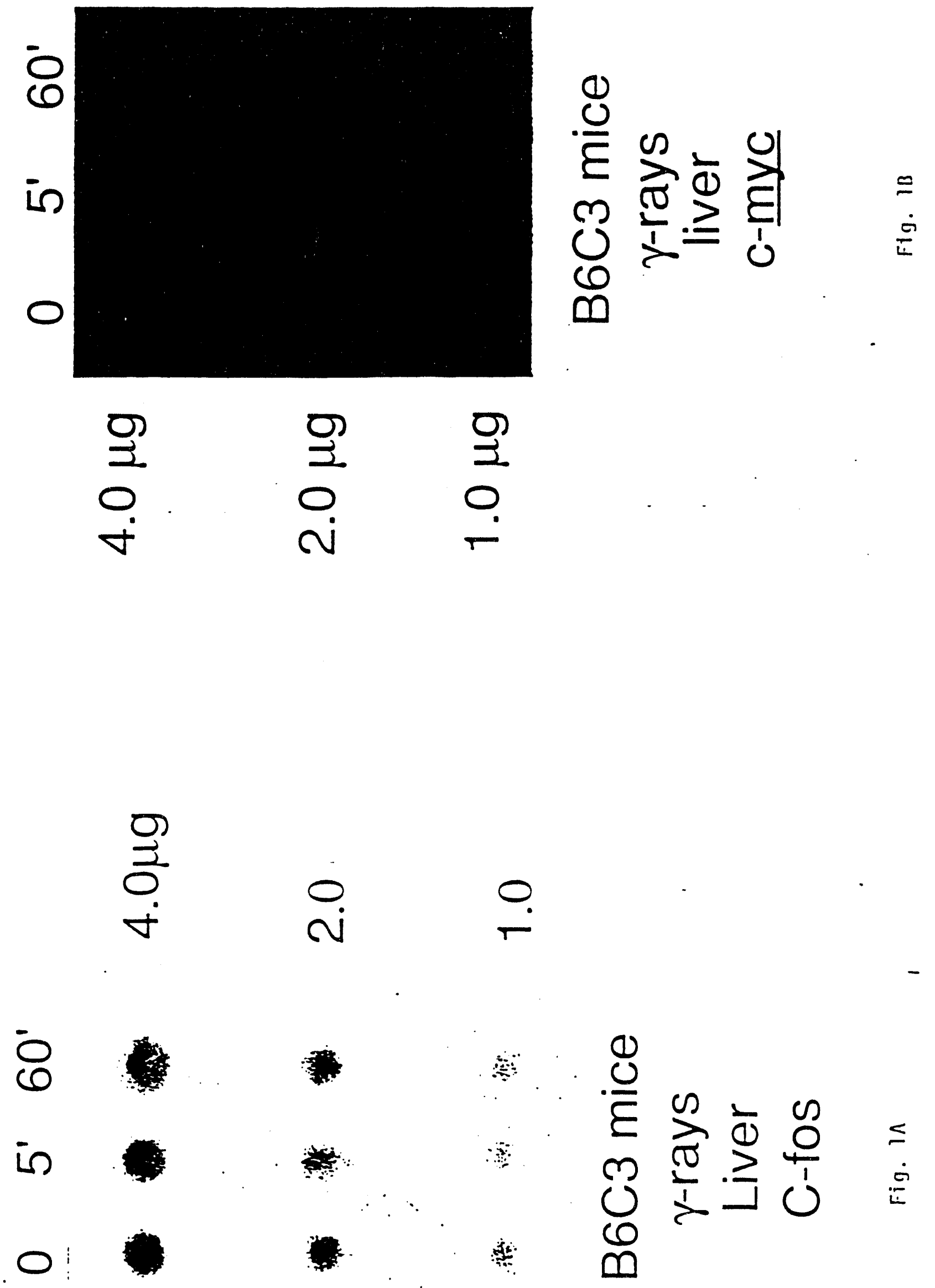


$$
01 \cdot 6+3
$$

\section{SEd-H-O \\ เә^!7 \\ shed-h \\ हО9Я}

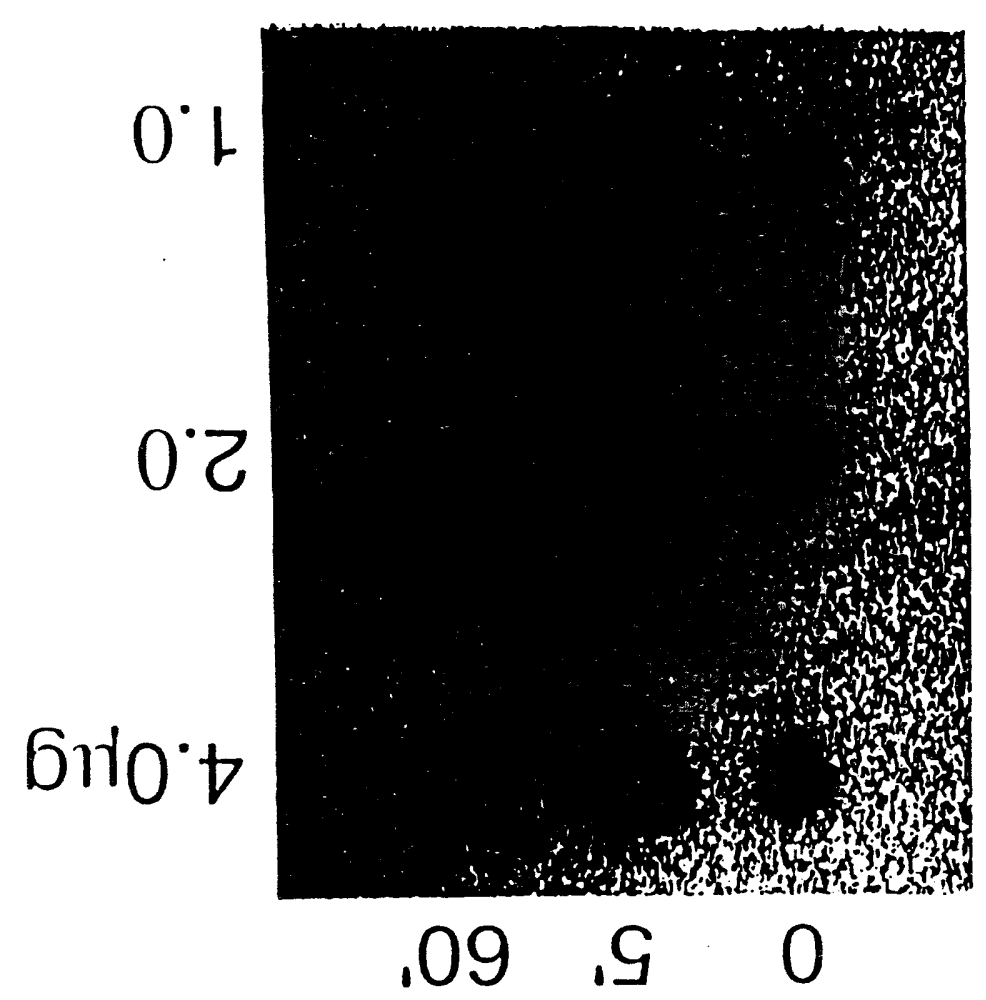

1

$3 ! \cdot 6 !]$
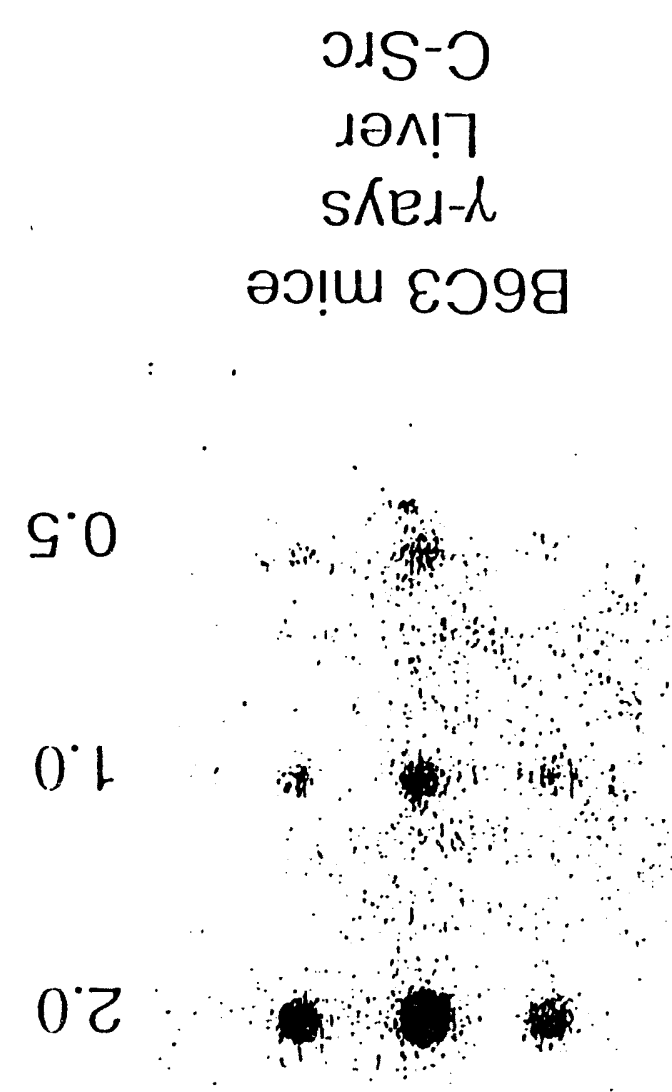

brtoto, 

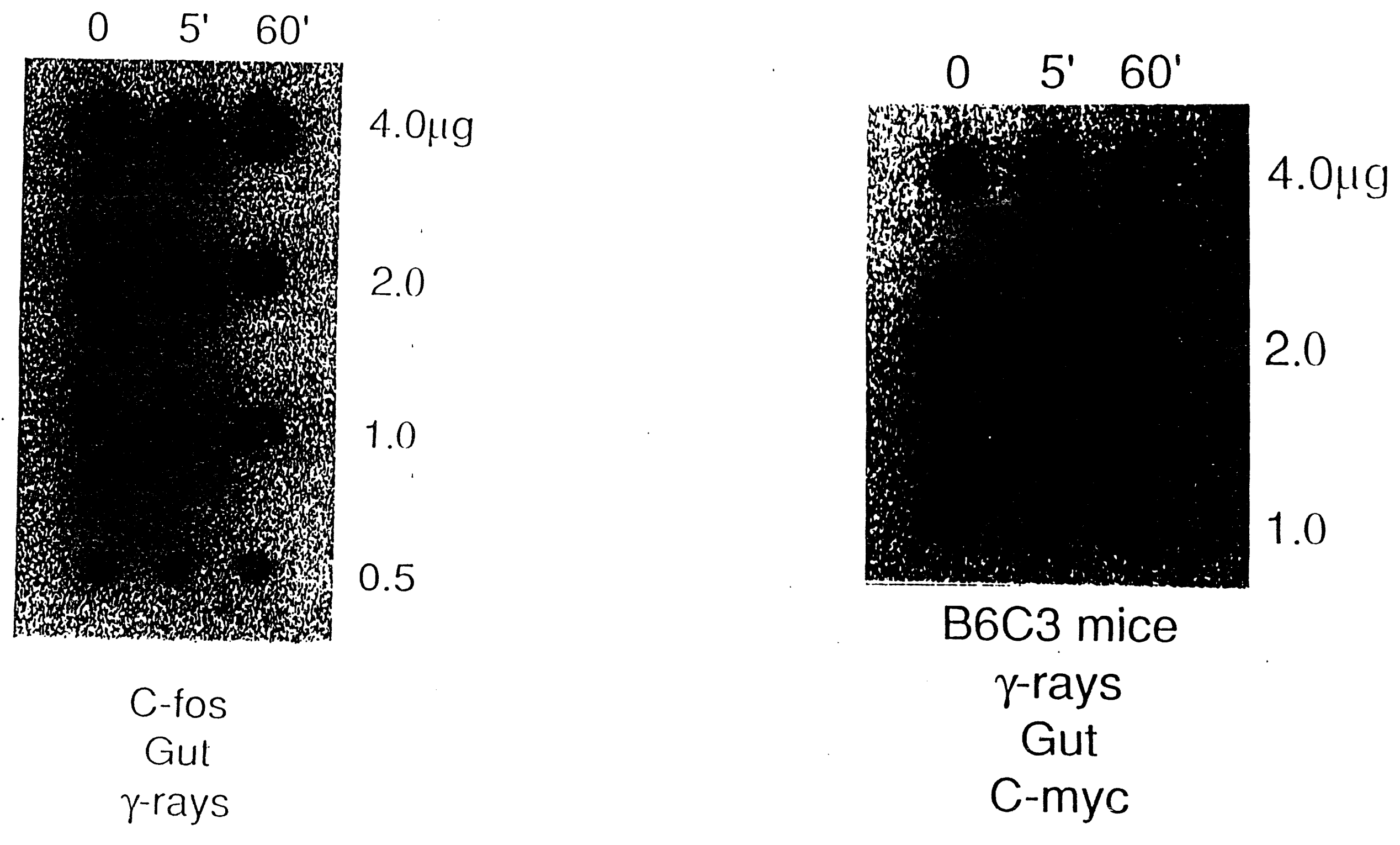

Fig. $2 \Lambda$

Fig. $2 B$ 


$$
02 \cdot 51 .
$$

sরed-d

ing

SEd-H

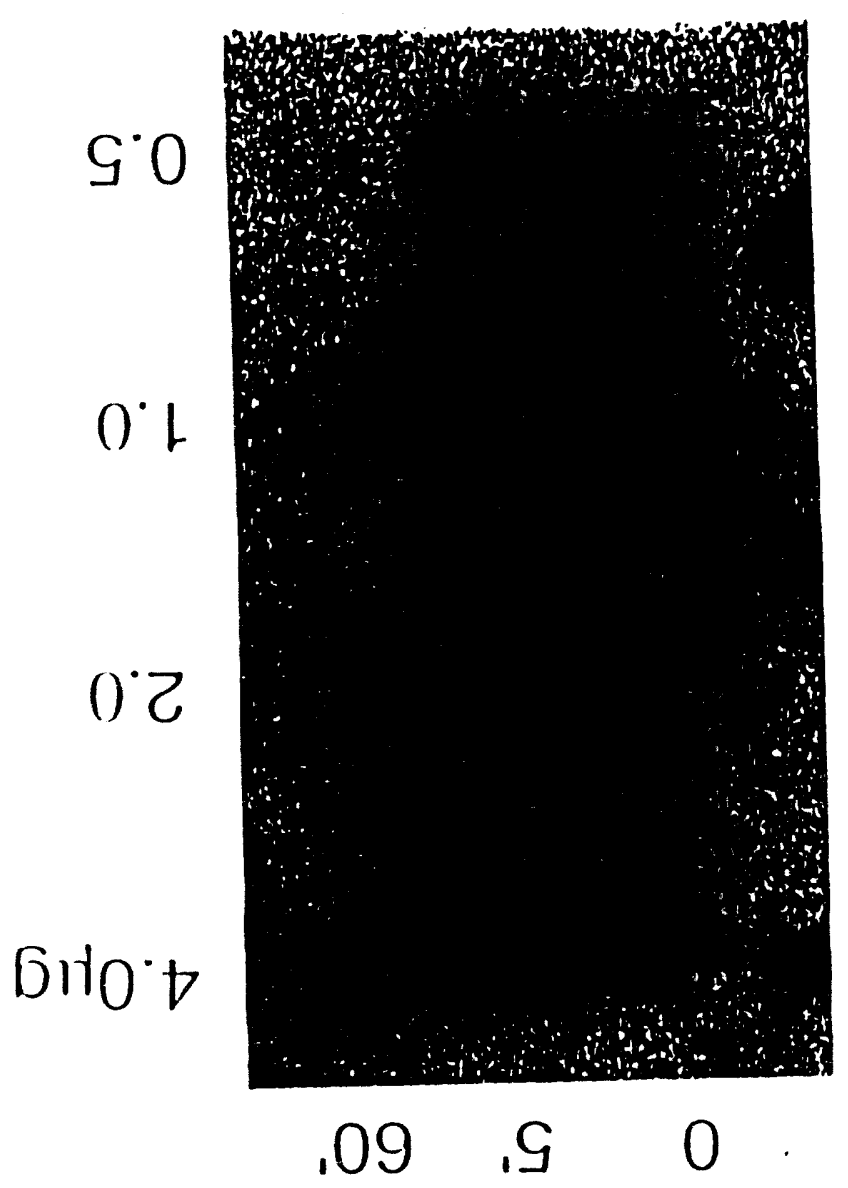

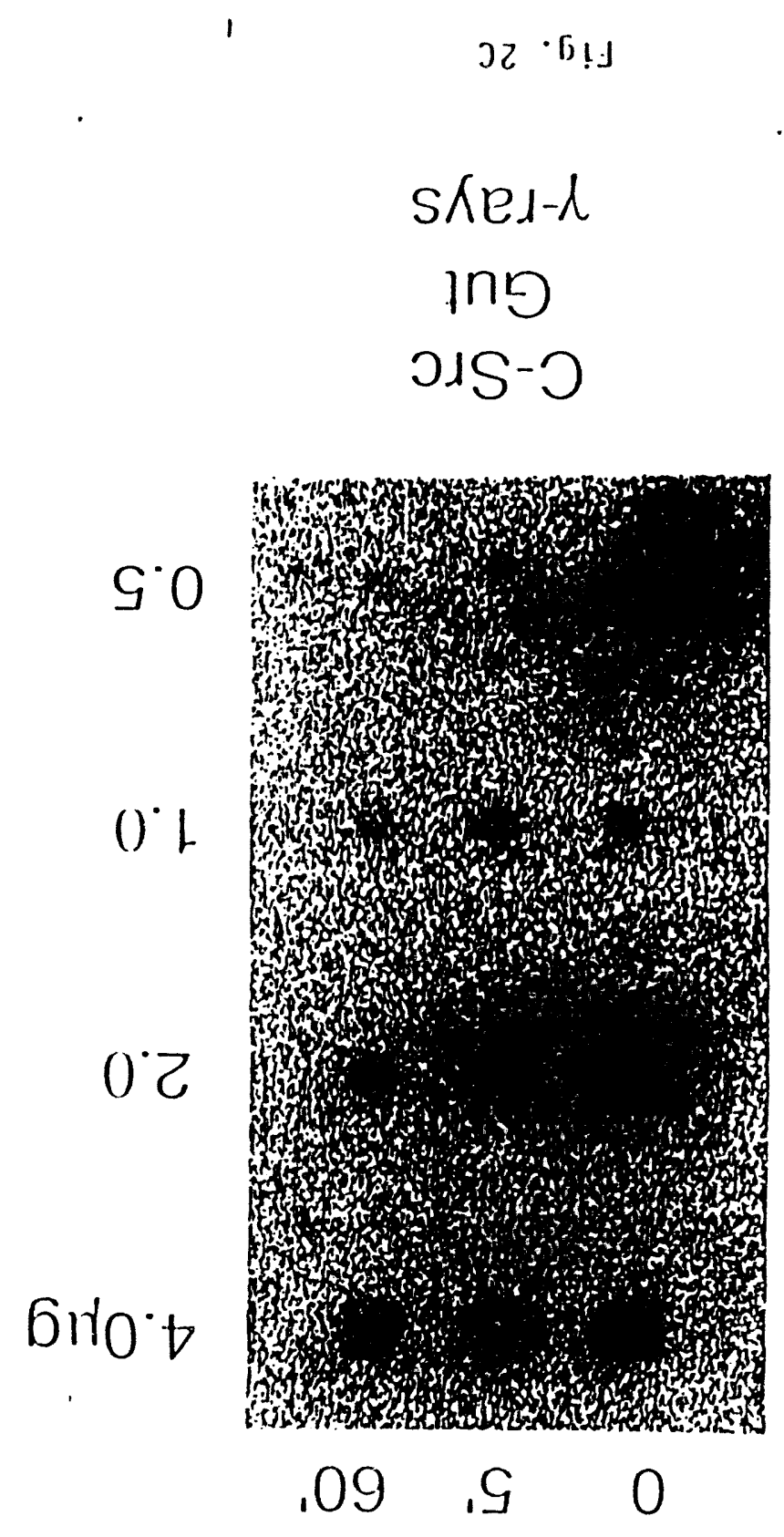



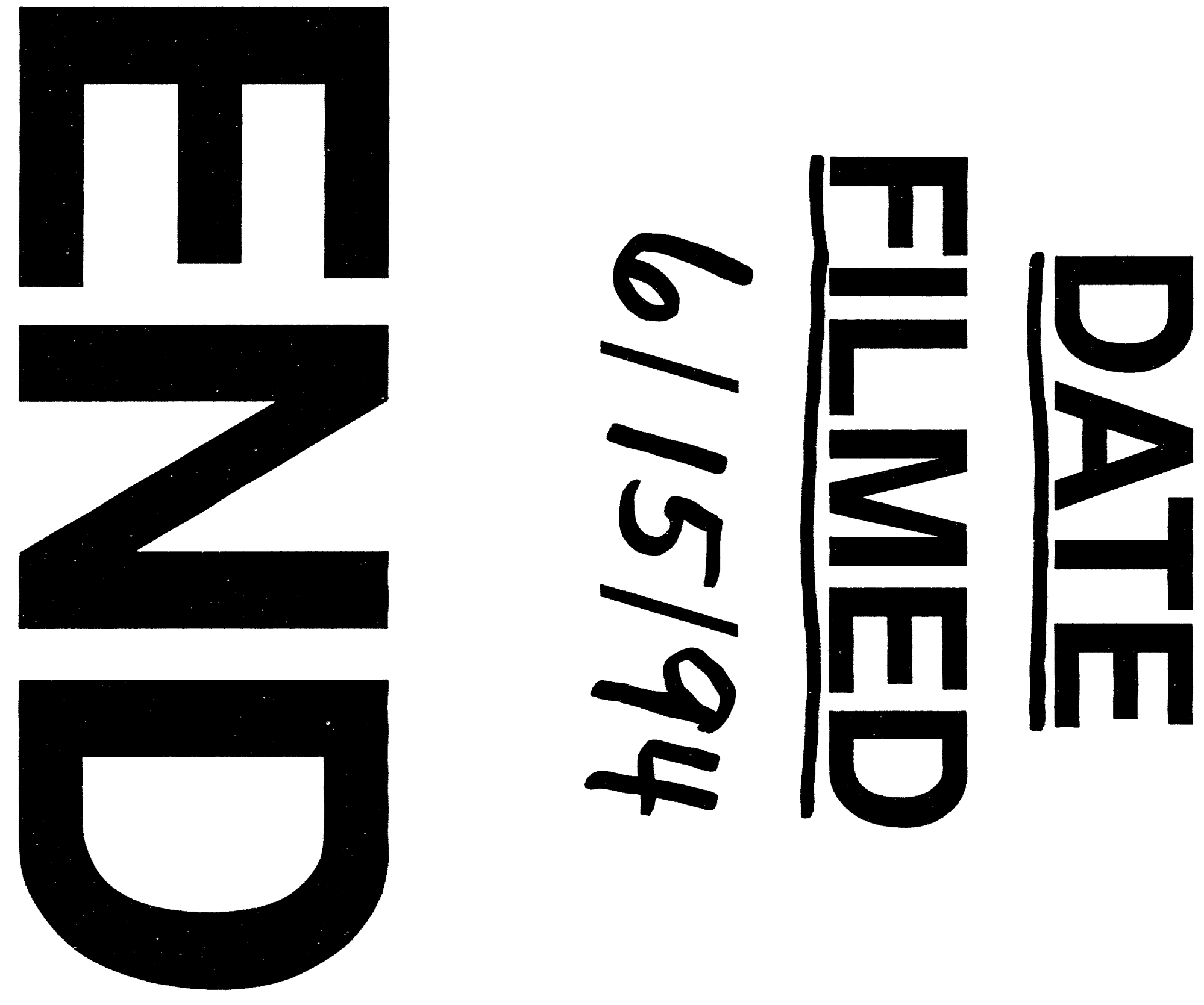
